(16) : Semipalmated Sandpiper, 28 (9); Marbled Godwit, 7 (29) ; American Avocet, 62 (38); Wilson's Phalarope, 27 (22) ; Northern Phalarope, $21(0)$; Herring Gull, $2(0)$; California Gull, 2 (0) ; Ring-billed Gull, 78 (106); Franklin's Gull, 10 (238) ; Forster's Tern, 2 (0): Common Tern, 43 (22); Black Tern, 20 (10);Rock Dove 81 (57); Mourning Dove, 62 (40); Great Horned Owl, 5 (1); Burrowing Owl, 2 (11) ; Long-eared Owl, 1 (0) ; Shortared Owl, 2 (0); Belted Kingfisher, 4 (11); Yellow-shafted Flicker, 38 (42); Red-shafted Flicker, 1 (0); Yellow-bellied Sapsucker, 2 (2) ; Downy Woodpecker, 1 (3) ; Eastern Kingsird, $16(0)$; Western Kingbird, 55 (6); Eastern Phoebe, 5 (6); Least Flycatcher, 63 (3) : Western Wood Pewee, $5(0)$; Olive-sided Flycatcher, 2 (0); Horned Lark, 415 (572); Tree Swallow, 139 (26); Bank Swallow, 21 (0); Cliff Swallow, 2 (1); Barn Swallow, 86 (10); Rough-winged Swallow, 1 (0); Purple Martin, 29 (32); Magpie, 42 (42) : Crow, 102 (105); Red-breasted Nuthatch, 14 (0); Brown Creeper, 1 (1); House Wren, 21 (1); Winter Wren, $1(0)$; Catbird, $4(0)$; Brown Thrasher, (4) (3) ; Robin, 160 (169); Hermit Thrush, 2 (2) : Swainson's Thrush, 81 (200) ; Graycheeked Thrush, 52 (93) : Veery, 1 (0) ; Eastern Fluebird, 2 (1); Ruby-crowned Kinglet, 2 (11); Sprague's Pipit, 2 (0) ; Loggerhead Shrike, 21 (17); Starling, 42 (32); Solitary Vireo, $2(0)$; Warbling Vireo, $2(0)$; Prothonotary Warbler, 1 (0); Black - and - white Warbler, 9 (0); Tennessee Warbler, $9(0)$; Crange-crowned Warbler, 11 (21); Yellow Warbler, 45 (9); Myrtle Warbler, 52 (204); Blackpoll Warbler, 9 (1); Pine Warbler, 1 (0); Palm Warbler, 2 (13) ; Ovenbird, 3 (0) ; Northern Waterthrush, 9 (6) : Yellowthroat, 1 (1): Wilson's Warbler, 1 (0); Redstart, 1 (1); House Sparrow, 457 (669): Bobolink, 4 (0): Western Meadowlark, 249 (276); Yellow- headed Blackbird, 53 (192) ; Red-winged Blackbird, 545 (698); Baltimore Oriole, 15 (1) Rusty Blackbird, 2 (2) ; Brewer's Blackbird, 226 (487); Common Grackle, 136 (179): Brown-headed Cowbird, 141 (136); Rosebreasted Grosbeak, 27 (1) ; Purple Finch, 20 (4); American Goldfinch, $18(0)$; Rufous-sided Towhee, 3 (3) ; Lark Bunting, 13 (0); Savannah Sparrow, 17 (55); Baird's Sparrow, 1 (0) ; Vesper Sparrow, 42 (82); Lark Sparrow, 1 (0) ; Chipping Sparrow, 52 (144); Claycolored Sparrow, 118 (160); Harris' Sparrow, 108 (177) ; White-crowned Sparrow, 93 (263); White-throated Sparrow, $90(212)$; Fox Sparrow, 2 (0); Lincoln's Sparrow, 18 (168); Swamp Sparrow 1 (11); Song Sparrow, 10 (21); McCown's Longspur, 82 (13); Lapland Longspur, $1252 \quad$ (5695); Chestnut-collared Longspur, 124 (55): Snow Bunting, 1 (0).

Total species, 150. Total individuals, 7909. Participants: Jessie Bailey, Father Bedard, Margaret Belcher, Al and Betty Binnie, Greg Bobbitt, Bill Brownlee, Marilee Cranna, Sandra Crooks, Betty Cruickshank, George Dodd, Pearl Guest, Gayl Hipperson, John Horton, Jim Jowsey, Fern Lawrence, George Ledingham, Christine MacDonald, Joyce Munn, Connie Pratt, Joe Roberts, Barbara Ross, Shirley Sather, Lorne Scott, Mrs. Sykes, Elisabeth Wagner, Holly Wallace, Janie Wilhelm, and 10 girls from St. Chad's Science Club.-Compiled by Al and Betty Binnie.

\title{
SPRING BIRD OBSERVATIONS ON LANGARA ISLAND, BRITISH COLUMBIA
}

\author{
by $\mathbf{R}$. Wayne Campbell, Burnaby, B.C.
}

In the spring of 1966 Norman larkson, Lowell Orcut, Ken Kennedy nd the writer visited Langara Island or the purposes of banding Ancient Murrelets, collecting birds for the University of British Columbia and collecting intertidal marine mollusca. since little is recorded on bird distrioution in the northwestern corner of the province, field notes were made on the birds encountered.

Langara Island lies just north of Graham Island (the largest island) (n the Queen Charlotte Islands Biotic 1 rea. The island is "slightly over five miles long and four miles wide at the videst point. The shores are precipious, the interior partly forested with conifers and partly muskeg" (Munro and Cowan, 1947). Sitka spruce (Picea sitchensis) is the climax tree with associated stands of western red cedar (Thuja plicata), western hemlock (Tsuga heterophylla) and lodgepole pine (Pinus contorta) being common. The trees are covered with beard moss (Usnea sp.) and the forest floor carpeted with salal (Gaultheria shallon) consequently making interior travel difficult.

The island is best known for its nesting Peregrine Falcons (Falco peregrinus) and is considered one of the few remaining strongholds for this magnificent bird in British Columbia. As well, Langara Island supports a large and varied population of breeding seabirds. (Drent and Gui- 


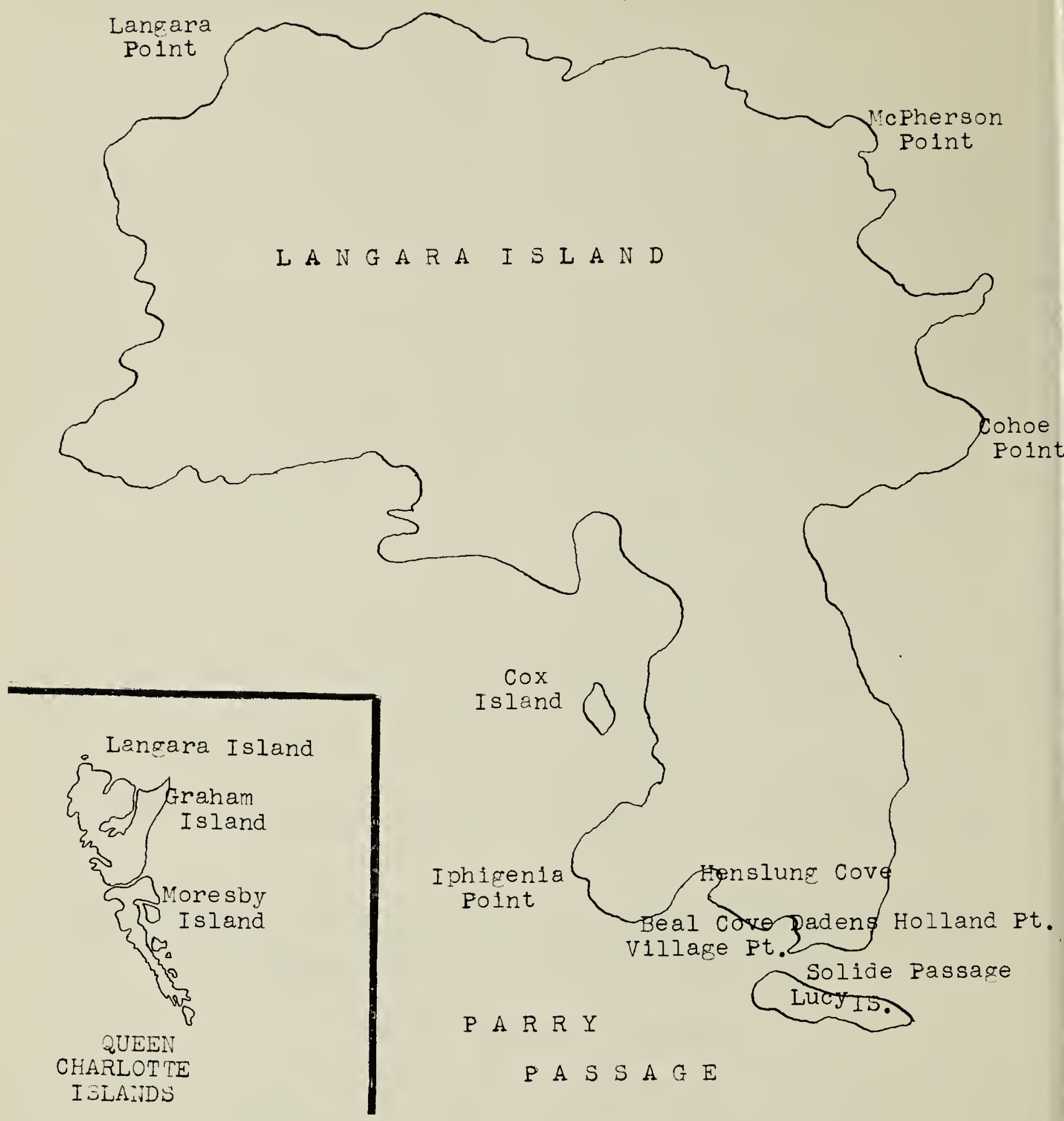

guet, 1961). These include Forktailed Petrel, Leach's Petrel, Pelagic Cormorant, Glaucous - winged Gull, Pigeon Guillemot, Ancient Murrelet, Cassin's Auklet, Rhinoceros Auklet and Tufted Puffin. Bald Eagles are also known to be in abundance on Langara Island.

Transportation about the island was confined to a small rubber raft. Paddling against strong currents, huge ocean swells and close to rocky shores made exploring the entire island difficult and hazardous. Consequently our observations, from April 28 through May 3, include only the southern portion of Langara Island, from about Cox Island south to the tip (see map).

\section{SPECIES ACCOUNT}

Arctic Loon Gavia arctica. An adult, in summer plumage, was seen in Beal Cove on May 2 and 3.

Red-necked Grebe Colymbus grisegena. Two adults, both in full summer plumage, were seen in Beal Cove on May 3.

Fork-tailed Petrel Oceanodroma furcata. On April 30 a check for petrel burrows was made around Cox Island. About 20 burrows, in various habitats, were excavated. No signs of 
the southe:n tip of the island. On May 3,34 were counted on a trip from Henslung Cove to Cohoe Point.

Three nests were located, each with incubating birds. Two nests, one near Iphigenia Point and another at Henslung Cove, could not be checked. One just north of Holland Point, however, contained one egg. Incubation had just started. The nest was a bulky structure of sticks about six feet in diameter and lined with cedar boughs. It was situated in a spruce tree about 30 feet above the ground.

Peregrine Falcon Falco peregrinus. Single birds were seen regularly during our stay. On April 30 three birds were seen together on Cox Island. An apparent nest with an incubating bird was located on the cliffs on Cox Island the same day.

Black Oystercatcher Haematopus bachmanii. Common along the beaches where it feeds on various forms of marine life, notably the limpets (Acmaeidae) and chitons (Amphineura). Usually two to six birds were recorded daily. On May 3 eight were seen flying together through Solide Passage. Two adults were collected.

Sanderling Crocethia alba. One, in breeding plumage, was seen in Beal Cove on May 2.

Glaucous-winged Gull Larus glaucescens. Common, regularly seen roaming the beaches during our stay. About 20 frequented the shores until May 1 when about 250 gulls were seen passing through Solide Passage. Numbers gradually increased until we left on May 3.

Mew Gull Larus canus. One sighting only of an adult in Beal Cove on April 28.

Pigeon Guillemot Cepphus columba. Common, especially in the Henslung. Cove area where about 50 were recorded daily. Two adults were collected.

Ancient Murrelet Synthliboramphus antiquus. Abundant, though seldom seen during the daylight hours near the breeding grounds. This species is a burrow nester, spending the day in large rafts offshore, coming to land during the late evening to exchange incubation duties. Wherever slope is sufficient the murrelet is likely to be found nesting but we found several nests, all with freshly broken shells (attributed to predation by Alexandrian Rats, Campbell, 1968b), in the rather level stretch of upper beach along Solide Passage.

On April 30 we checked several grassy slopes north of Holland Point for possible active burrows. Of 28 fresh-looking burrows checked, one contained two eggs, 11 contained one egg and the remainder were empty. No adults were found incubating. Eggs in the completed clutch measured (in inches) $2.41 \times 1.52$ and $2.35 \mathrm{x}$ 1.46. On May 2 and 3 we spent the evenings on the steep hills north of the Indian Reservation of Dadens. The grounds here were riddled with murrelet burrows. About 7:30 p.m. we could see the birds begin to gather in large flocks in Parry Passage. The flight to the colony or breeding grounds started about $10: 30$ p.m. and was mostly completed by midnight. The birds would fly directly into the trees or thick salal beds, fall to the ground, and scamper off to their respective burrows. By night-lighting (Campbell, 1968a) we captured and banded several birds.

Four adults were collected on May 2.

Saw-whet Owl Aegolius acadicus. This small owl was fairly common in the open grassy fields near Dadens. An adult male was collected on May 1.

Rufous Hummingbird Selasphorus rufus. A single adult male was present near Village Point throughout our stay. It was very aggressive, likely defending a territory.

Belted Kingfisher Megaceryle alcyon. An adult male was seen on April 29 and 30 diving in Beal Cove.

Downy Woodpecker Dendrocopos pubescens. Present throughout our stay, often see searching tree trunks behind Dadens.

Tree Swallow Iridoprocne bicolor. At least six birds were regularly seen around Beal Cove during our stay.

Common Raven Corvus corax. A common bird, often seen soaring over 
the centre of the island. On April 28, 20 were seen, another 15 on May 3.

Northwestern Crow Corvus caurinus. Abundant, especially on an ebbing tide. At least 40 fed daily among the intertidal zone in Beal Cove. On May 3, 55 were recorded from Holland Point to Cohoe Point.

Chestnut-backed Chickadee Parus rufescens. Common, inhabiting the interior forested areas of the island. On May 2 a pair was observed excavating a nest cavity.

Winter Wren Troglodytes troglodytes. This species was more often heard than seen; however, three birds were s een near Holland Point on April 29.

Varied Thrush Ixoreus naevius. Two were heard near Beal Cove on April 29 and one was seen in the same area the following day.

Savannah Sparrow Passerculus sandwichensis. Not recorded until May
2 when birds became quite common along the log-littered beaches. Three specimens were collected.

Song Sparrow Melospiza melodia. Common among the low brush and grass areas near Dadens. Two adults were collected.

\section{SUMMARY}

Field notes have been documented on 38 species of birds recorded from the southern portion of Langara Island in six days during spring migration in 1966.

\section{LITERATURE CITED}

American Ornithologists' Union. 1957. Checklist of North American birds. Fifth ed. Baltimore, Maryland.

Campbell, R. W. 1968a. Capturing Ancient Murrelets by Night-lighting. Blue Jay $26: 2$. Campbell, R. W. 1968 b. Alexandrian rat predation on ancient murrelet eggs. Murrelet $49: 2$.

Drent, R. H., and C. J. Guiguet. 1961. A catalogue of British Columbia sea-bird colonies. B.C. Prov. Mus. Occ. Papers No. 12.

Munro, J. A., and I. McT. Cowan. 1947. A Review of the bird fauna of British Columbia. B.C. Prov. Mus. Spec. Publ. No. 2.

\section{SIXTEEN NEW BIRD RECORDS FOR MANNING PARK, B.C.}

by Kenneth R. Beckett, Park Naturalist 4484 Markham Road RR \# 3, Victoria, B.C. Under the British Columbia Nature Interpretation Program, park naturalists keep records of bird sightings in the various parks as part of their work from June to early September. In Manning Park, located between Hope and Princeton on the southern Trans Provincial Highway, the first check list was compiled in the late 1950 's. Since then new "finds" each vear usually amounted to a few species with a resultant total list in 1966 of 148 varieties. Through the combined efforts of four interested park naturalists during the past two vears, 16 new species have been added to this list to bring the 1968 total to 164. These new records are as follows: Arctic Loon; Red-necked, Horned, Eared and Pied-billed grebes; Shoveler, Redhead and Ruddy ducks; Common Snipe; Mew Gull; Arctic Tern; White-winged Scoter; Blackchinned Hummingbird; Cliff Swallow; House Sparrow and American Goldfinch.
Because the Similkameen valley reaches westward from the Okanagan into the southern portion of this 176,431-acre park and the Gibson Pass leads on through the northern Cascade Mountains, many birds use this route either by choice or chance during the fall migration. Again, individuals and small groups moving up in the spring from Ross Lake in Washington State into Canada may fly this same route in the opposite direction. In either case, careful daily checking along the Similkameen River, the Lightning Lakes chain (four small lakes), and the Gibson Pass area will undoubtedly prove fruitful again. Birds migrating through this park often stop over briefly, perhaps only an hour or two, and can slip by unnoticed. This makes the study of bird movements unpredictable and frustrating as it so often is; but, at the same time, deeply rewarding in unusual sightings. Our 16 park records were such rewards.

A check list of the birds of Manning Park can be obtained by writing the Parks Branch, Legislative Buildings, Victoria. 